Abant Tıp Dergisi

Olgu Sunumu / Cilt 9 Sayı 2 Yıl 2020

\section{Abant Medical Journal}

Case Report / Volume 9 Issue 2 Year 2020

\title{
Atipik Seyirli Sekonder Pnömonik Tularemi
}

\section{Atipic Secondary Pneumonic Tularemia}

Pınar Almıla Bücük ${ }^{1}$ iD , Fatma Sırmatel ${ }^{2}$ iD

${ }^{1}$ 1.Murat Edirne Devlet Hastanesi, İç Hastalıkları Bölümü, Edirne - Türkiye

${ }^{2}$ Bolu Abant İzzet Baysal Üniversitesi Tıp Fakültesi Enfeksiyon Hastalıkları ABD, Bolu - Türkiye

\section{Öz}

Tularemi endemik bölgelerde farklı klinik tabloda görülebilir. İki ay önce boğaz ağrısı, ateş ve sonradan kilo kaybı, kesilmeyen öksürük, şikâyeti ile gelen bir bayan hasta. Yapılan kan biyokimyasında lökositoz (12.500/mm3), hemoglobin $9.9 \mathrm{gr} / \mathrm{dl}$, sedimantasyon (103 mm/saatte), CRP (109 mg/l), ALT(61 I.U) ve AST (54 I.U) yüksekliği saptanmış. Hasta ampisillin tedavisine rağmen düzelme göstermemiş. Çekilen akciğer grafisinde hiler lenfadenomegali, lobular ve nodüler tutulum görülmüş ve bronkoskobide kitle saptanmıştır. Hastada, radyolojik olarak akciğer kanseri düşünülürken, şikâyetlerinin patates tarlasında çalıştıktan sonra geliştiği fark edilmiştir. Yapılan serolojide tularemi antikor testinin 1/1280 de pozitif gelmesi ile olgu sekonder pulmoner pnomoni olacağı düşünülmüştür. Hasta verilen üçlü antibiyotik tedavisi (streptomisin+doksisiklin+ciprofloksasin) ile tamamen düzelmiştir. Tulareminin nadir bir şekli olan pulmoner tutulum endemik bölgelerde akciğer kanseri ile karıştırılabilir. Olgu sunularak pnömonik tularemi literatürler eşliğinde gözden geçirildi.

Anahtar Kelimeler: tularemi, öksürük, pnomoni

\section{Abstract}

Tularemia can be seen in different clinical pictures in endemic regions. A women who came with a complaint of sore throat, fever (380 C) and subsequent weight loss, unceasing cough, and complaints continuing for 2 months. In the blood samples, leukocytosis $12.500 / \mathrm{mm} 3$ hemoglobin $9.9 \mathrm{~g} / \mathrm{dl}$, sedimentation rate $103 \mathrm{~mm} /$ hour, level of C-reactive protein $109 \mathrm{mg} / \mathrm{l}$, alanine aminotransferase $61 \mathrm{i} . \mathrm{u}$ and aspartate aminotransferase $54 \mathrm{i.u}$ were determined. The patient did not improve despite the ampicillin treatment. Hilar lymphadenomegaly, lobular and nodular involvement were seen on the $\mathrm{X}$-ray chest and a mass was confirmed by bronchoscopy. It was noticed that the patient developed his complaints after working in the potato field while considering lung cancer radiologically. In the serology when the tularemia antibody test was positive at $1 / 1280$, it was thought that the case would be secondary pulmonary pneumonia. The patient recovered completely with the triple antibiotic treatment (streptomycin, doxycycline and ciprofloxacin) given. Pulmonary involvement, a rare form of tularemia, can be confused with lung cancer in endemic areas. The case was presented and pneumonic tularemia was reviewed with the literature.

Keywords: tularemia, cough, pneumoniae

\section{Giriş}

Tularemi, Gram negatif kokobasil olan, Francisella tularensis'in, etken olduğu, ağırlıklı olarak Kuzey yarım kürede görülen bir zoonotik enfeksiyon hastalığıdır (1). Türkiye'de çoğunlukla su ile bulaştığı bilinen tulareşekilmi, laboratuvarda çalışanlar, çiftçiler, veterinerler, avcılar, doğa sporları yapanlar ve kırsal bölgede yaşayanlarda da mesleki olarak görülebilir (2). Tularemi altı farklı klinik tabloda görülmesine rağmen nadir olarak değişik klinik tablolarda gösterebilir (3-6). Genelde endemik bölgelerde görülen bu farklı klinik tablolar, rutinde olmayan serolojik tanı yöntemi nedeni ile geç konulmakta, bazen olgu tanımlamasında geç kalınmaktadır (710).

Tularemi kliniği tutulum durumuna göre primer ve sekonder olarak tanımlanır. Primer tutulum lokalize, sekonder tutulum ise primer odaktan yayılarak ikincil organ tutulumu şeklinde tanımlanır $(8,11)$. Ülsero-glanduler tularemiden sonra pulmoner tutulum ile seyreden pnömonik tularemi olguları ülkemizden şimdiye kadar çok az olgu olarak sunulmuştur $(1-3,10)$. Yapılan pubmed ve cochrane taramasında, etken suşun serotipine göre, primer pulmonik tularemi ciddi 
ve mortal, sekonder pulmoner tularemi ise daha ziyade bakteriyemi ve ikincil organ tutulumu ile gelişebilir (11-14). Pnömonik tularemi daha ziyade Amerika da tavşan avcılarında veya üzüm bağlarında çalışan işçilerde sık görülmesine rağmen bildirilen yayınlarda şimdiye kadar bizim olgumuza benzer az olgu tanımlanmıştır $(7,9,15)$.

Sunulan olguda oral tutulum sonucu gelişen sekonder pnömonik tularemi olgusu akciğer görüntülemesinde kanser olarak değerlendirilmiştir. Olgunun tularemi olabileceği hastanın önce boğaz ağrısı, sonradan öksürük şikayetleri olması bize sekonder pnömoniyi düşündürmüştür. Ancak patetes tarlasında çalışma sonucu inhalasyonla almış olması ihtimalinde maruziyeti göz önüne alınırsa primer olması beklenirdi. Tulareminin birden fazla klinik ile seyir göstermesi mümkün olabilmektedir. (1619). Fakat bölgemizde köylerimizde kaynak suları kullanımı yaygındır. Genelde bizde ülseroglandüler tularemi görülmesine karşın bu olguda ilginç olan boğaz tutulumundan sonra akciğer tutulumunun olması, kliniğin kanser ile karıştırıması ve bronkoskobide eksudalı kitlenin inflamasyon olarak gelmesidir. Olguyu sekonder pulmoner tularemi olarak tanımlarken bu ikilemi yaşadık. Ancak alınan kitlede bakteriyi izole etme şansımız olmadı. Fakat hastanın uygun antibiyotikle düzelmesi pulmoner tularemiyi doğrulamıştır. Endemik bölgelerde değişik klinik tularemi tabloları olabileceği düşünülerek ve olguyu sunarak literatürü gözden geçirdik.

\section{OLGU SUNUMU}

İki ay önce boğaz ağrısı, ateş ve kuru öksürük nedeni ile ampisillin grubu antibiyotik tedavisi alan 30 yaşında bir bayan hasta. Hastanın yaygın el ve yüzünde döküntüleri olunca ileri tetkik için üniversite hastanesine gönderilmiş. Cildiye polikliniğinde Sweet Sendromu tanısı alan hasta, kesilmeyen öksürük, sedim ve CRP yüksekliği nedeni ile göğüs hastalıkları bölümüne sevk edilmiş. Çekilen akciğer grafisinde sağ hiler lenfadenopati (şekil 1) saptanmış. Hastanın akciğer tomografisinde, mediastinal çoklu lenf nodları, sağ hilusta kitle, konglemere lenfadenomegali, ayırımı yapılamayan hipodens lezyon, sağ akciğer alt lopta süperiyör segmentde düzensiz kontürlü kaviter lezyon (şekil 2) olarak rapor edilmiştir. Hastanın laboratuvar olarak kan biyokimyasında lökosit (12.500/mm3), sedimantasyon (103 mm/saatte), CRP (109 mg/l), ALT (61 l.U) ve AST (54 I.U) yüksekliği ve hemoglobin ( $9.9 \mathrm{gr} / \mathrm{dl})$ düşüklüğü dışında başka bir patoloji saptanmamıştır. Tanı amaçlı yapılan bronkoskobide, sağ üst lop karinasında, üzeri eksudalı kitle görülmüş ve histolojik incelemede granulomatöz enfeksiyon olarak sonuç gelmiştir. Hastanın sorgulamasında boğaz ağrısının patates tarlasında çalışıp toprak çapalamasından sonra geliştiği öğrenilince yapılan tularemi serolojisi 1/1280 titrasyonunda pozitif bulunmuştur. Hastaya tularemiye yönelik antibiyotik tedavisi düzenlenmiştir. Tedavide doksisiklin (2x100 mgr/gün) +streptomisin (on gün $2 \times 1 \mathrm{gr} /$ gün, sonra haftada $2 \mathrm{kez} 2 \times 1 \mathrm{gr} / \mathrm{gün}$ ) ve siprofloksasin (2×500 mgr/gün) toplam 21 gün kullanılmıştır. Hastanın tedaviden sonra şikayetlerinin azaldığı, ateşinin kaybolduğu ve yapılan izlemde akciğerdeki sağ lober tutulumun tamamen kayıp olduğu ve hiler lenf nodüllerinin küçüldüğü saptanmıştır. Hastanın klinik olarak öksürüğünün kesildiği, izlemde kan biyokimyasının ve radyolojik bulgularının ikinci ayda tamamen düzeldiği görülmüştür.

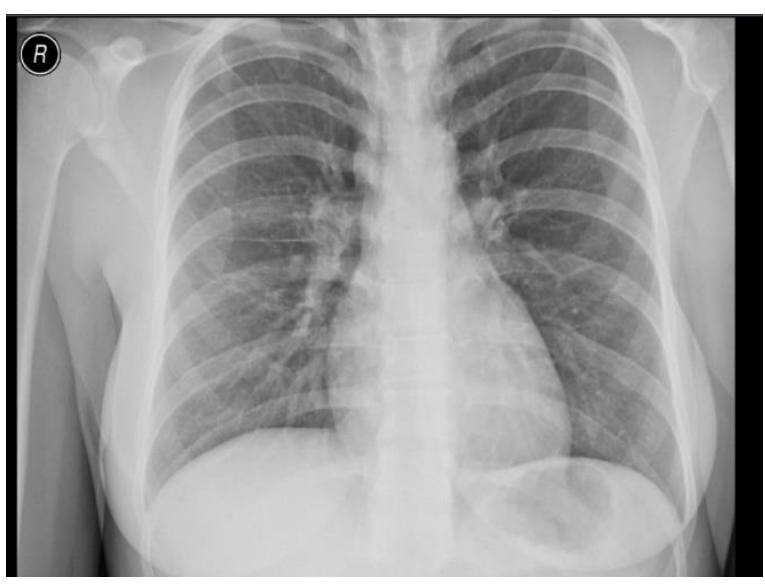

Şekil 1. Hastanın x-ray akciğer grafisinde hiler dolgunluk. 


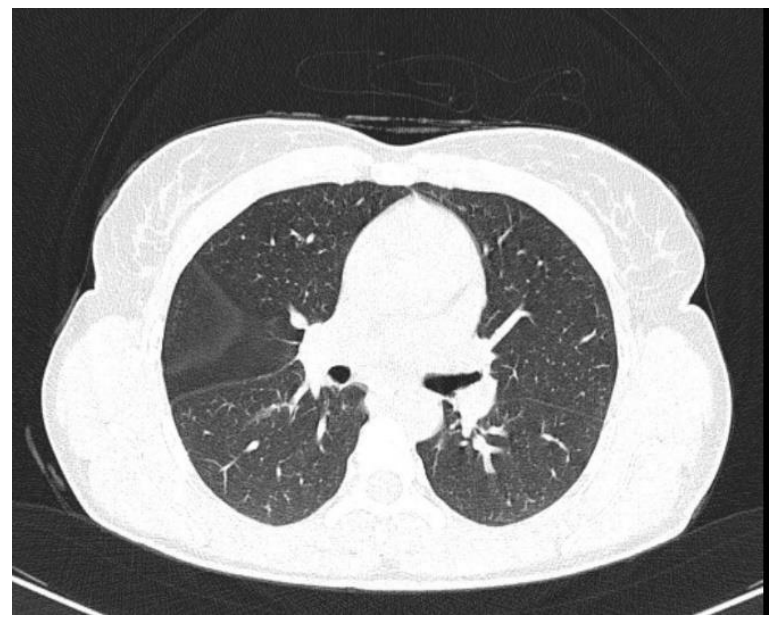

Şekil 2. Hastalı̆̆ın başlangııında çekilen akciğer tomografisinde sağ akc de kaviter tutulumu ve hiler lenfadenopati nodullerinin görünümü

\section{IRDELEME}

Tularemi dünyada farklı coğrafi alanlarda değişik tiplerde görülen zoonotik bir hastalıktır $(8,10,15)$. Insanlara oral, inhalasyon ve temas yolu ile doğada bulunan, küçük kemiricilerden direk veya indirek olarak bulaşır. Tavşan ateşi denilen hastalık, yıllardan beri bilinen bir zoonotik hastalık olarak, özellikle son yıllarda biyolojik silah olarak da gündeme gelmiştir. Etkeni olan Francisella tularensis ( $F$. tularensis), dört tip olarak [F. tularensis (tip A), F. holarctica (tip B), F. mediasiatica ve $F$. Novicidia] bilinir ve hastalığın patogenenezinde tür durumu önem arz eder $(7,11,13)$. Sharma ve ark (11) yaptığı çalışmada A tipini inhale olarak farelere vermiş ve aşırı sitokin salınımı ile ciddi sepsis tablosunu izlemişdir.

Kuzey yarımküre ve ülkemizde görülen $F$. holarctica daha az virulandır. Ülkemizde en fazla oral yoldan yağmurlu mevsimlerde doğal kaynak sularının içilmesi ile salgınlar yaptığı bilinmektedir $(1,2,10)$. Orofaringeal formun sık görüldüğü bölgemizde salgın yaşadığımız dönemde izlenen 68 olgunun sadece üçünde öksürük görülmüştür (2). Primer pnömonik tularemi direk inhalasyon ile bulaşan plevral efüzyon ve ciddi solunum yetmezliği ile görülen ölümcül bir tablodur $(7,11)$. Sekonder pnömonik tularemi ise ulseroglanduler veya tifoidal tularemi sonucu, akciğer dokusunda hiler, noduler ve kaviter tutulum ile görülen daha hafif bir klinik tablodur $(6,7,14)$

Bölgemizde tulareminin pik yaptığı bir dönemde olgumuz orofaringeal tutulum ile gittiği doktor tarafından boğaz enfeksiyonu nedeni ile ampisillin tedavisine alınmış ancak hastamızda cilt döküntüsü olunca cildiye polikliniğine gönderilmiştir. Cildiyede sweet sendromu tanısı alan hastamız sedim, CRP, karaciğer enzim yüksekliği ve kesilmeyen öksürük nedeni ile göğüs hastalıklarına yönlendirilmiştir. Göğüs hastalıklarında inceleme sırasında akciğer tutulumu detaylı olarak incelenmiştir. Olgunun akciğerde görülen sağ hiler ve kaviter lezyonunu kanserden ayırt etmek için yapılan bronkoskobisinin sonucu granülomatöz enfeksiyon olarak gelmiştir.

Tularemi olgularında sweet sendromu görülmesi daha önce Polat ve ark. (5) tarafından üç olgu ile bölgemizden sunulmuştur. Tularemide cilt tutulumu \%8-35 oranında görülür $(2,5,8)$. Olgumuzda sweet sendromu görülmesi ilacın yan etkisine veya yetersiz tularemi tedavisine bağlı olabilir. Tularemide pulmoner tutulum nadir raslanan bir durumdur. Tulareminin pulmoner tutulumu bazı yayınlarda noduler tutulum nedeniyle kanser ile karıştırılabilir $(9,14)$. Hastamızın yapılan bronkoskobisinde, sağ bronş üzerinde eksudalı lenfadenopatiler ve kitle görülmüş, sonuçta alınan materyel granulomatöz inflamasyon olarak bulunmuştur. Hastanın tüberküloz, bruselloz, sarkoidoz açısından inceleme sonuçları negatif olarak gelmiş ve tularemi antikor titrasyonu pozitif (1/1280) olarak saptanmıştır. Akciğerde kanseri taklit eden ve noduler tutulumu olan tularemi olguları nadir görülür $(7,13,14)$. Pnömonik tularemide radyolojik olarak peribronşiyal infiltratlar, lober konsolidasyonlar, plevral efüzyon ve hiler adenopatiler görülebilir. Radyolojik tutulumlar klinik, serolojik ve histolojik bulgularla birlikte değerlendirilmelidir. Olgumuzda zayıflama olması ve sedimantasyon yüksekliği, radyolojik görüntülemeler, kanseri desteklemiş olmasına rağmen histolojik bulgular kronik granulomatöz 
enfeksiyonu doğrulamıştır. Hasta kronik granülomatöz enfeksiyon açısından detaylı incelenerek, sarkoidoz, tüberküloz, bruselloz gibi hastalıkları dışlanmış ve serolojik pozitifliği ile tularemi tanısı almıştır.

Tularemi olgularında uygun antibiyotik ile hastaların şikayetleri düzelmekte, etkili olmayan beta laktam grubu antibiyotiklerle hastalığın persistan seyrettiği bilinmektedir. Tedavide aminoglikozid ile iyi sonuç alınmaktadır $(4,8,15)$. Bizim hastamızda üçlü antibiyotik ile iyi sonuç alınmıştır. Streptomisinin kullanım şekli yan etki nedeni ile ilk on gün yüksek doz ve sonraki iki haftada aralıklı kullanılmıştır. Daha önceden hastanın boğaz enfeksiyonunda, kullanılan beta laktam grubu antibiyotikler etkili olmamış ve glanduler form belkide sekonder pnomonik tularemiye neden olmuş, hatta akciğerde glandüler form gelişmiş olabilir. Ülseroglandüler forma sekonder gelişen pnömonik tularemi olgusu şimdiye kadar yapılan incelemede dört olguda izlenmiş (7) ancak ülkemizden çok az olgu bildirilmiştir $(2,6,16,17)$

Pulmoner tularemi genelde inhalasyon ile gelişir. Fachinger ve ark (9) tarafından bildirilen dört olguda pulmoner tutulum sekonder olarak kabul edilmese de inhalasyon yolu ile bulaşarak primer pulmoner tutulum olacağı düşünülmüştür. Yazar bu sunumda akciğerde noduler, hiler tutulumun malignite ile karışacağına dikkat çekmiş ve serolojinin pozitifliği ve antibiyotik tedavisine cevabın olmasını tanı için yeterli olabilir diye, öneride bulunmuştur (10). Olgumuzun anemnezin de toprak ile uğraşması sonucu inhalasyon ile bulaş söz konusu olabilir. Ancak bölgemiz tularemi için endemik bir alandır. Muhtemelen hasta tularemiyi oral ve/veya inhale olarak almış olabilir. íki klinik formun bir arada görülebileceği hastaların mesleki maruziyetleri açısından değerlendirilmesi gerekir.

Pulmoner tularemi sepsis ile seyrederek mortalitesi yüksek bir klinik tablo oluşturur (11). Ancak bizim ülkemizde görülen tularemi olguları fazla patojen olmayan tür olup daha ziyade ülsero-glandüler formda görülür. $\quad A B D^{\prime}$ den bildirilen dört olguda hastaların tavşanlar ile teması dikkati çekmiş ve radyolojik olarak hiler lenfadenomegalileri ile pnomonik tularemi tanımlamaları yapılmıştır $(11,14)$. Son zamanlarda Ankara'dan bildirilen bir pulmoner tularemi ise önce boğaz sonra akciğer tulumu olacağı düşünülen bir pulmoner tularemi olgusu vardır (6). Pulmoner tularemi tanısında bronkoalveoler aspirasyonda tularemi bakterisinin moleküler, serolojik ve immunflouresan yöntemle gösterilmesi önerilmiş olsada, halen yüksek serolojik titrasyon ve antibiyotik tedavisine cevap tanı için yeterli olmaktadır $(8,16)$.

Radyolojik olarak pulmoner tularemi değişik tutulumda noduler, lober ve plevral formlarda da görülebilir ve kanser ile karıştırılabilir (12-14). Çoğu zaman serolojisi geciken ve klinik olarak, boğaz enfeksiyonu ile karışan olgularda bildirilmiştir (15). Olgumuzun tedaviden sonra klinik ve radyolojik düzelmesi de pulmoner tutulumu desteklemektedir. Tulareminin kesin tanısı seroloji ve kültürdür $(15,17)$. Kültür yapılması özel ortam gerektirdiği için bölgemizde şüphelendiğimiz olguların tanısında serolojiyi kullanmak zorundayız. Olgumuzun başlangıçta orofaringeal tutulumu olmuş ancak glandüler şekli akciğerde olmasından dolayı gözden kaçmıştır. Radyolojik görüntülemeler her ne kadar kanser düşündürse de histolojik bulgular granülomatöz enfeksiyonu doğrulamıştır. Tularemide granülomatöz görünüm ve konglomere lenfadenomegali görünümü spesifiktir (16).

Tularemi olgularında titrasyon başlangıçta negatif olmasına rağmen özellikle izah edilemeyen durumlarda geç dönemde pozitifleşme saptanmaktadır $(4,15)$. Endemik bölgelerde boğaz ağrısı ve ateş nedeni ile gelen olgularda lenfadenomegali nedeninde, akciğer enfeksiyonları da düşünülmelidir. Endemik alanlarda pnömonik tulareminin ayırt edici 
tanısında serolojik inceleme akla gelmeli ve tedavi seçeneklerinde dikkatli olunması gerektiğine inanıyoruz.

Bilgilendirilmiş Onam: Katılımcılardan yazılı onam alınmıştır.

Çıkar Çatışması: Yazarlar çıkar çatışması beyan etmemişlerdir.

Finansal Destek: Yazarlar finansal destek beyan etmemişlerdir.

\section{KAYNAKLAR}

1. Sahin M, Atabay HI, Bicakci Z, Unver A, Otlu S. Outbreaks of Tularemia in Turkey. Kobe J. Med. Sci 2007; 53(1): 37-42.

2. Korkmaz T, Bicer YÖ, Sirmatel Ö, Sirmatel F. A retrospective analysis of tularemia cases admitted to a tertiary care hospital. Kulak Burun Boğaz Uygulamaları 2013;1(1):11-16

3. Bayındır T, Can Ş, Bayındır Y, Kızılay A. Bozok Tıp Derg 2014: 1(1); 54-9,

4. Arslanyılmaz M, Aslan D, Akın L, Aktaş D. Türk Hijyen ve Deneysel Biyoloji Dergisi. 2014;71(2):99-106

5. Polat M, Parlak AH, Ors I, Sirmatel F. Erythema nodosum and Sweet's sybdrome in patients with glandular tularemia. International Journal of Dermatology 2011; 50:866-69

6. Gürbüz $Y$, Gülmez ZD, Tütüncü EE, Şencan I: Bir Tularemil Pnömoni Olgusu. Klimik Dergisi 2019; 32:2010-12

7. Matyas BT, Nieder HS, Telford SR. Pneumonic tularemia on Martha's Vineyard: Clinical epidemiologic and ecological characteristic. Ann NY Acad Sci 2007; 1105:351-77

8. Rimawi RH, Shah KB, Chowdhary RA, and Cook PP. Hunting for tularemia-A review of cases in North Carolina. Zoonoses Public Health 2015; 62:159-64

9. Fachinger P, Tini GM, Grobholz R, Gambazzi F, Fankhauser $\mathrm{H}$ and Irani S. Pulmonary tularemia: All that looks like cancer is not necessarily cancer. Case report of four consecutive cases. BMC Pulm Med 2015; 15:1-6

10. Gürcan Ş. Epidemiology of tularemia. Balkan Med J 2014; 31:3-10

11. Sharma J, Mares CA, Li Q, Morris EG, Teale JM. Features of sepsis caused by pulmonary infection with Francisella tularensis Type A strain. Microb Pathog 2011; 51:39-47

12. Ranjbar R, Behzadi $P$, Mammina C. Respiratory Tularemia; Francisella Tularensis and Microarray Probe Designing. Open Microbiol Journal 2016; 10:176-82

13. Alias T, Fallahzadeh MK, Berhe M. Tularemia presenting as pulmonary nodules in an immuncompromised patient. Baylor Univ Med Cent Proc 2017; 30:175-76

14. Naughton M, Brown R, Adkins D, Dipersio J. Tularemia. An unusual cause of a solitary pulmonary nodüle in the posttransplant setting. Bone Marrow Transplant 1999; 24:19799

15. Aktepe E, Sönmezer MC, Yarımoğlu S, Erdiç FS, Ertem G, Tülek N. Geç tanı konulan ülseroglandüler tularemi: Bir olgu sunumu. Klimik Der 2017; 30(2):83-6.

16. Erzurumluoğlu N, Sargan A, Yildiz FR, Ozekinci S,
Mersinlioglu G. A suppurative granulomatous lymphadenitis agent. Tularemia case report. Med J Okmeydanı Train Res Hosp 2018; 34:41-5

17. Erdem H, Ozturk DE, Yesilyurt M. Et all. Evaluation of tularemia courses: A retrospective study from Turkey. Clin Microbiol Infect 2014; 20: 1042-51.

18. Çelebi G. Klimik sayfası- https://www.klimik.org.tr/bilgimerkezi/tularemi/tularemi-yrd-doc-dr-guven-celebizonguldak-karaelmas-universitesi-tip-fakultesi 